\title{
An Emerging Disease Caused by Pseudomonas syringae pv. phaseolicola Threatens Mung Bean Production in China
}

Suli Sun, Ye Zhi, and Zhendong Zhu, National Key Facility for Crop Gene Resources and Genetic Improvement, Institute of Crop Sciences, Chinese Academy of Agricultural Sciences, Beijing, 100081, China; Jing Jin, Agronomy and Plant Protection College, Qingdao Agricultural University, Qingdao, 266109, China; and Canxing Duan, Xiaofei Wu, and Wang Xiaoming, National Key Facility for Crop Gene Resources and Genetic Improvement, Institute of Crop Sciences, Chinese Academy of Agricultural Sciences

\begin{abstract}
An emerging bacterial disease with symptoms resembling those of halo blight is threatening mung bean production in China. This study was conducted to investigate the disease's geographic distribution in China using consecutive multiyear field surveys and to confirm the causative agents' identity. The surveys were conducted in 15 provinces covering seven geographic regions from 2009 to 2014. The survey results revealed that the emerging mung bean disease has rapidly spread and is prevalent in three of the main Chinese geographic regions, which contain more than $90 \%$ of the mung-bean-growing areas in China. To confirm the causal agent, diseased mung bean leaves were collected from the surveyed fields

and used to isolate the pathogen. A bacterium was consistently isolated from all of the collected leaves. Based on the phenotypic characteristics, the physiological and biochemical properties, pathogenicity tests, and fatty acid composition, in combination with specific polymerase chain reactions and 16S-23S ribosomal DNA sequence analyses, the bacterium was identified as Pseudomonas syringae pv. phaseolicola. To our knowledge, this is the first report of $P$. syringae pv. phaseolicola causing halo blight on mung bean in China. The results indicate that $P$. syringae pv. phaseolicola is likely of epidemiological significance on mung bean in China.
\end{abstract}

Mung bean (Vigna radiata $\mathrm{L}$.) is an important warm-season legume crop widely grown in tropical and subtropical regions in Asia (Nair et al. 2013). It has been cultivated extensively in several geographic regions of China (Wang et al. 2009). Mung bean is considered a rich source of dietary protein, iron, carbohydrates, and micronutrients, as well as bioactive compounds with medicinal values (Dahiya et al. 2015). Additionally, its products have appeared in various processed foods which are popular in China, Korea, the Philippines, and Thailand (Dahiya et al. 2015; Silva et al. 2013; Tang et al. 2014; Zeng et al. 2011). Biotic stresses are major factors limiting the yield and quality of mung bean. To date, there are more than 20 diseases of mung bean documented in China (Zhu and Duan 2012). Numerous new mung bean diseases have been reported in China in recent years (Cui et al. 2014; Yue et al. 2015; Zhang et al. 2011).

Pseudomonas syringae is a widespread bacterial species comprising more than 60 pathovars with a broad host range (Young 2010). Most of the pathovars have highly restricted or specific host ranges, and are only pathogenic to a single plant genus or related host taxa (Lamichhane et al. 2015; Young 2010). However, the pathovar P. syringae pv. phaseolicola (Burkh.) has a relatively wide host range, infecting several crops, including Phaseolus vulgaris, P. acutifolius, P. coccineus, P. lunatus, Cajanus cajan, Centrosema sp., Desmodium spp., Glycine max, Lablab purpureus, Lens culinaris, Macroptilium atropurpureum, Neonotonia wightii, Pachyrhizus erosus, Pisum sativum, Pueraria lobata, P. thunbergiana, Vigna angularis, $V$. radiata, and $V$. unguiculata (Birch et al. 1981; Hunter and Taylor 2006; Patel and Walker 1965; Taylor et al. 1996). Pseudomonas syringae pv. phaseolicola, the causative agent of halo blight, is probably the most important bacterial pathogen of bean (Phaseolus

Corresponding author: Z. Zhu; E-mail: zhuzhendong@ caas.cn

S. Sun and Y. Zhi contributed equally to this work.

*The $\boldsymbol{e}$-Xtra logo stands for "electronic extra" and indicates that one supplementary figure and one supplementary table are published online.

Accepted for publication 11 August 2016.

C) 2017 The American Phytopathological Society vulgaris) in Europe and the United States, as well as other countries (Rico et al. 2003). Bean halo blight disease was first observed in the United States in 1925. It reduced average yields by up to $45 \%$ and further losses occurred due to the poor quality of the infected pods (Arnold et al. 2011; Burkholder 1926; Webster et al. 1983). To date, the disease has been observed in most bean-growing regions worldwide and has become a highly destructive disease on bean. The bean halo blight pathogen favors cool (less than $25^{\circ} \mathrm{C}$ ) and moist conditions. Severe epidemics of the disease can result in bean yield losses as high as 80 to $100 \%$ in regions with cool and humid climates (van Schoonhoven and Voysest 1989).

Pseudomonas syringae pv. phaseolicola is a serious seedborne pathogen, and even extremely low levels of seed infestation can result in severe epidemics under favorable weather conditions (Webster et al. 1983). Therefore, the only practical and effective control treatment for this disease is the use of pathogen-free seed (Taylor et al. 1979; Webster et al. 1983). Thus, the detection of $P$. syringae pv. phaseolicola in seed is essential for effective disease management. The certification of seed as pathogen-free requires highly sensitive and specific identification and detection methods for $P$. syringae pv. phaseolicola. To date, many countries, including China, have strict quarantine laws against $P$. syringae pv. phaseolicola due to its seedborne status (Li et al. 2009; Yang et al. 2015). The pathogen P. syringae pv. phaseolicola can produce a chlorosis-inducing toxin, phaseolotoxin, which causes the characteristic chlorotic halo surrounding water-soaked spots on infected leaves (Bender 1999; Mitchell 1976; Tamura et al. 2002). The phaseolotoxin synthetic gene clusters of $P$. syringae pv. phaseolicola have been isolated and identified (Mosqueda et al. 1990; Peet et al. 1986; Zhang and Patil 1997; Zhang et al. 1993). Subsequently, several simple and efficient methods for the specific detection of toxigenic strains of $P$. syringae $\mathrm{pv}$. phaseolicola have been developed based on the phaseolotoxin gene cluster sequences (Audy et al. 1996; Mosqueda-Cano and Herrera-Estrella 1997; Prosen et al. 1993; Schaad et al. 1995). Nontoxigenic strains of $P$. syringae pv. phaseolicola were also found in the field (Rico et al. 2003). These strains were pathogenic and could produce typical water-soaked lesions but could not cause chlorotic halo symptoms or spread systemically in the plant. It was generally thought that they had little or no epidemiological significance to halo blight of bean (Schaad et al. 1995). In Spain, Rico et al. (2003) found that the nontoxigenic strains were a main causal agent of halo blight in bean. Nontoxigenic strains could not be detected using previous molecular 
and serological methods. Therefore, Rico et al. (2006) established a reliable method to distinguish toxigenic and nontoxigenic strains of P. syringae pv. phaseolicola. Primer pair P3004 L/P3004R, which amplified a $0.24-\mathrm{kb}$ fragment only in nontoxigenic $P$. syringae pv. phaseolicola strains, has been developed (Oguiza et al. 2004; Rico et al. 2006). A duplex polymerase chain reaction (PCR) amplification with two primer pairs, P3.1/P5.1 and P3004 L/P3004R, specific for toxigenic and nontoxigenic strains of $P$. syringae $\mathrm{pv}$. phaseolicola, respectively, could be simply and effectively used to identify and detect $P$. syringae pv. phaseolicola in seed (Rico et al. 2006).

Mung bean halo blight, caused by $P$. syringae pv. phaseolicola, was first recorded in the United States in 1971 (Schmitthenner et al. 1971). Subsequently, Patel and Jindal (1972) observed halo blight on mung bean in India. To date, mung bean halo blight disease has also been documented in Pakistan, Australia, and Tanzania (Akhtar 1988; Conde and Diatloff 1991; Taylor et al. 1996).

In China, halo blight caused by $P$. syringae pv. phaseolicola on bean was first reported in Heilongjiang Province in 1987, and it resulted in more than 50\% yield losses (Li and Zhang 1990). Recently, halo blight disease of bean was observed in Yunnan Province, although it is still considered a quarantine organism in China (Chen and Zhou 2013). In 2009, an emerging bacterial disease resembling halo blight was observed on mung bean plants grown in the northeastern region of China during our field disease survey of food legumes (Zhu and Duan 2012). The diseased mung bean plants showed typical symptoms on infected leaves that were similar to those of halo blight (Harveson and Schwartz 2007). Subsequently, the disease rapidly spread and emerged in many mung-bean-planting areas, which caused serious mung bean yield losses, making the disease a major threat to mung bean production in China. Thus, it is necessary to investigate the geographic distribution of this disease in order to know it prevalence and response to the disease control.

The objective of this study was to investigate the geographic distribution of the emerging disease resembling halo blight on mung bean in China through consecutive multiyear field surveys and characterize the causal agent of the emerging disease using morphological observations, physiological and biochemical tests, and molecular characteristics, including specific PCR amplification reactions and 16S-23S ribosomal DNA (rDNA) sequence analyses, as well as pathogenicity tests.

\section{Materials and Methods}

Field surveys of disease distribution. Our previous field observation indicates that the emerging disease resembling halo blight is becoming a major threat to mung bean in China. In this study, the distribution of mung bean halo blight in China was conducted by consecutive multiyear field surveys in 15 provinces, including all mung-bean-growing areas and covering seven geographic regions of China: northeastern, northern, northwestern, eastern, central, southwestern, and southern China (Fig. 1). The surveys commenced in 2009 and continued until 2014, spanning 6 years. Consecutive multiyear field surveys will demonstrate the disease occurrence and prevalence as well as symptom development process on mung bean.

Sample collection and pathogen isolation. To determine the identity of the pathogen causing the emerging disease, infected mung bean leaves with severe symptoms of halo blight, necrotic spots surrounded by a yellow halo, were collected from the surveyed fields located in the northeastern, northern, northwestern, eastern, central, southwestern, and southern regions of China (Fig. 1).

To isolate the putative causal agent, the boundary areas of the lesion tissues on mung bean leaves were cut into small pieces, which were then surface disinfested in $2 \%$ sodium hypochlorite for $2 \mathrm{~min}$, followed by rinsing three times in sterile distilled water. The disinfested pieces were crushed in sterile 1.5 -ml tubes containing $600 \mu \mathrm{l}$ of sterile distilled water. The resulting suspensions or dilutions were streaked onto King's B (KB) medium plates (King et al. 1954). The plates were incubated at $28^{\circ} \mathrm{C}$. After 3 to 5 days of incubation, white colonies that fluoresced under UV light were

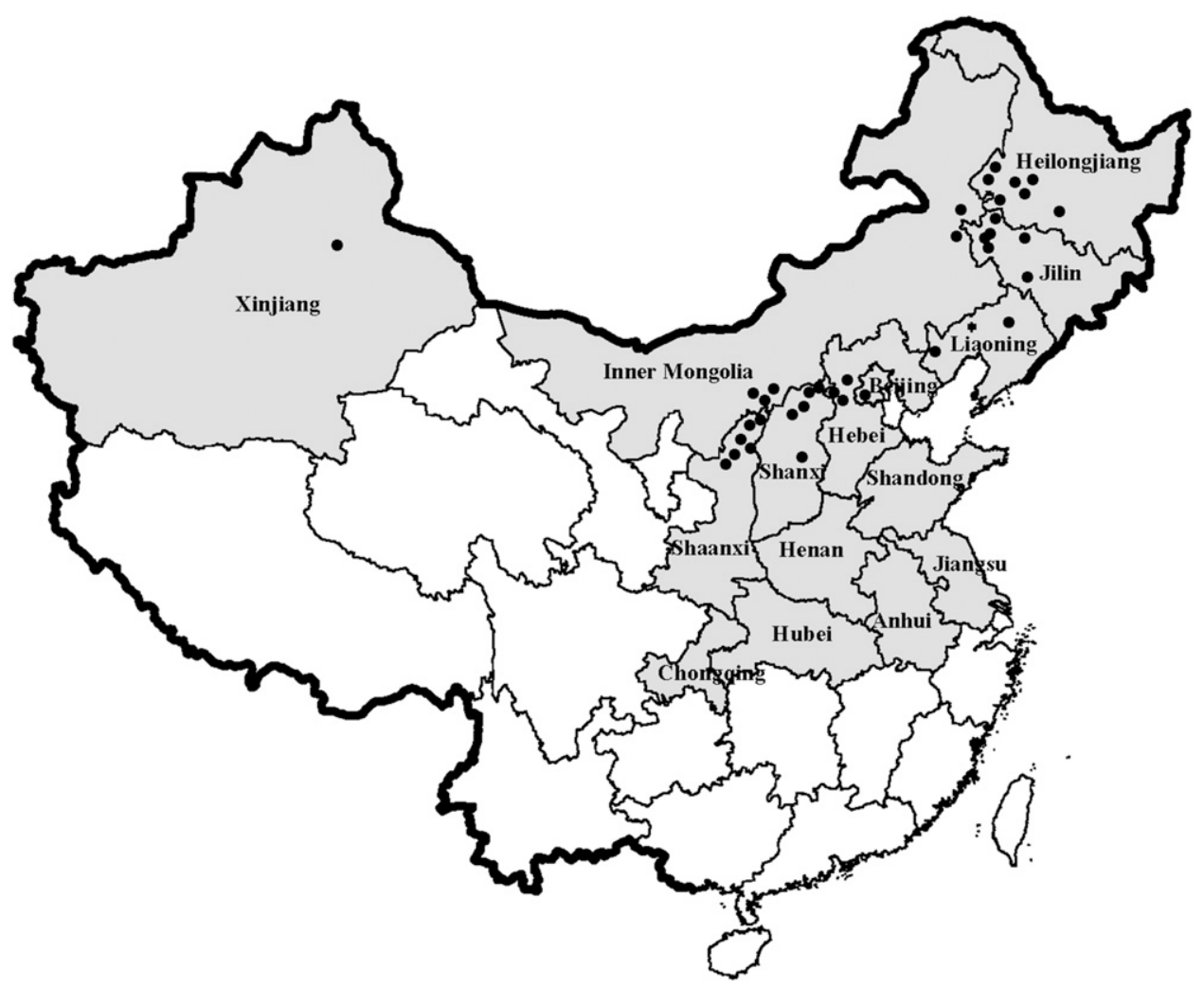

Fig. 1. Geographic distribution of mung bean halo blight as determined by consecutive multiyear field surveys in China. Gray, shaded regions represent provinces in which the surveys were conducted. Black dots indicate cities or counties where mung bean halo blight has occurred. 
purified using single-colony subcultures. The cultured bacterial cells were suspended in $\mathrm{KB}$ plus $15 \%$ glycerol and stored at $-80^{\circ} \mathrm{C}$ until further use.

Pathogenicity tests. Nine representative isolates from nine provinces were selected for pathogenicity testing. The pathogenicity tests were performed on 2-week-old seedlings of Chinese elite mung bean 'Jilv 7', which appears highly susceptible to the pathogen in the affected fields. Pathogen-free seed of Jilv 7 were kindly provided by Prof. Tian Jing at Hebei Academy of Agricultural and Forestry Sciences, Hebei Province, China. Seed were sown in paper cups (10 $\mathrm{cm}$ in diameter) filled with a $3: 1$ mixture of vermiculite and peat moss. Five seeds were sown per pot. The planted pots were placed in a greenhouse with temperatures of 23 to $27^{\circ} \mathrm{C}$ and natural daylight. For preparing inoculum, the nine representative isolates were cultured on nutrient broth agar (NA) medium for $48 \mathrm{~h}$. The inoculum was made by suspending the bacterial cells in sterile tap water to an approximate cell concentration of $1 \times 10^{8} \mathrm{CFU} / \mathrm{ml}$ measured by a ultraviolet spectrophotometer. The plants having the first fully expanded trifoliate leaves were inoculated using a leaf water-soaking method (Schuster 1955). Bacterial suspensions were sprayed onto the underside of leaf surfaces using a sprayer connected to a high-pressure air compressor (Haiou, Jiangyan City, China). Plants inoculated with sterile tap water were used as controls. Three hours after inoculation, the plants were placed in a mist room at 18 to $20^{\circ} \mathrm{C}$ for $48 \mathrm{~h}$. Misting occurred for 30 min every $2 \mathrm{~h}$ by an automatically controlled centrifugal humidifier, which maintained leaf wetness without excessive runoff. Then, the plants were removed to a greenhouse maintained at 18 to $22^{\circ} \mathrm{C}$ until the plants were rated for disease symptoms. After disease symptom development (i.e., 10 days after inoculation), bacteria were reisolated from infected tissues to complete Koch's postulates.

Phenotypic characteristics. Nine representative isolates from nine provinces were selected for morphological observations. The colony morphology of the nine isolates was observed on $\mathrm{KB}$ and NA media growing at $28^{\circ} \mathrm{C}$ for $72 \mathrm{~h}$. Bacterial cell morphology from the colony growth on NA at $28^{\circ} \mathrm{C}$ for $24 \mathrm{~h}$ was characterized using a transmission electron microscope (HITACHI H-7500; Tokyo).

Physiological and biochemical properties. Nine representative isolates were physiologically and biochemically analyzed. For the physiological analysis, the carbon source utilization of the isolates were determined using mannitol, inositol, sorbitol, erythritol, betaine, anthranilate, homoserine, trigonelline, D-tartrate, L-tartrate, and L-lactate (Schaad et al. 2001). For the biochemical analysis, gram staining reactions and the levan formation, oxidase reaction, potato soft rot, arginine dihydrolase, tobacco hypersensitive (LOPAT) tests were conducted following the methodology described by Lelliott et al. (1966). Each test was repeated at least twice.

Fatty acid composition. The nine bacterial isolates were inoculated onto NA medium and grown at $25^{\circ} \mathrm{C}$ for $24 \mathrm{~h}$, then transferred onto trypticase soy broth agar (Sigma-Aldrich, St. Louis) and grown at $28^{\circ} \mathrm{C}$ for $48 \mathrm{~h}$ to determine the fatty acid composition. The cellular fatty acids of the nine isolates were extracted and their fatty acid methyl esters (FAME) were separated according to the standard Microbial Identification System (MIDI) protocol (Microbial ID, Inc., Newark, DE). The FAME were then dissolved in hexane and analyzed by gas chromatography using an Agilent 6890 N GLC (Agilent Technologies, Palo Alto, CA) equipped with a 7683 injector, a G2614A autosampler, a flame ionization detector, and hydrogen as carrier gas. Conditions (temperature and time) for the gas chromatography analyses are set by MIDI (Sherlock version 4.5; Microbial ID, Inc.). FAME peaks were analyzed using MIDI, Sherlock MIS4.5 (microbial identification system) and LGS4.5 (library generation software)

Pathovar-specific PCR detection of the isolates. Total bacterial genomic DNA was extracted from the nine representative isolates grown on NA at $25^{\circ} \mathrm{C}$ for $72 \mathrm{~h}$ using the TIANamp Bacteria DNA Kit (Tiangen Biotech Co., Ltd., Beijing) according to the manufacturer's instructions. DNA of the nine isolates was amplified using four pathovar-specific primer pairs: HB14F/HB14R (Audy et al. 1996), 62a/63a (Mosqueda-Cano and Herrera-Estrella 1997), P3.1/ P5.1 (Schaad et al. 1995), and P3004 L/P3004R (Rico et al. 2006). Detailed information on the primers used in this study is listed in Table 1.

PCR amplification assays were conducted in a total volume of $20 \mu \mathrm{l}$, containing $50 \mathrm{ng}$ of genomic DNA, $2.5 \mu \mathrm{l}$ of $10 \times$ PCR buffer $\left(20 \mathrm{mM} \mathrm{MgCl}_{2}\right), 0.2 \mathrm{mM}$ each dNTP, $1.5 \mathrm{U}$ of Taq DNA polymerase (Tiangen Biotech Co., Ltd.), and $0.2 \mu \mathrm{M}$ primer mixture. PCR assays were carried out at $94^{\circ} \mathrm{C}$ for $5 \mathrm{~min}$; followed by 35 cycles of $94^{\circ} \mathrm{C}$ for $30 \mathrm{~s}, 50$ to $68^{\circ} \mathrm{C}$ (depending on the primer-specific annealing temperature) for 30 to $90 \mathrm{~s}$, and $72^{\circ} \mathrm{C}$ for 1 to $2 \mathrm{~min}$; with a final extension at $72^{\circ} \mathrm{C}$ for $10 \mathrm{~min}$, using a thermal cycler (Biometra, Goettingen, Germany). PCR products were separated by electrophoresis on a $1 \%$ agarose gel with $1 \times$ Tris-borate-EDTA buffer.

16S-23S rDNA sequence and phylogenetic analysis. The 16S-23S rDNA internal transcribed spacer (ITS) regions of three representative isolates (LDI7, LDI8, and LDI9) were amplified with the universal primer pair 1493F/23R (AGTCGTACCAAGGTAGCCGT/GTG CCAAGGCATCCACC) (Li and de Boer 1995). PCR assays and amplification were carried out as described above. The resulting purified amplicons produced by 1493 F/23R were sequenced. Sequencing reactions were performed at the Beijing Genomics Institute. The resulting sequences were analyzed as query using the BLAST algorithm against the National Center for Biotechnology Information (NCBI) GenBank database. A phylogenetic analysis was performed using the neighbor-joining method, and a phylogenetic tree was constructed by bootstrapping using Mega 6 software (Tamura et al. 2013).

\section{Results}

Field surveys of disease distribution. In 2009, a field survey of diseases affecting food legume crops was initially conducted in the northeastern region of China during their growing season. An emerging bacterial disease resembling halo blight was observed to be severely affecting mung bean in experimental and commercial fields located in Wulanhaote City and Tuquan County in Inner Mongolia Province; Baicheng City and Songyuan County in Jilin Province;

Table 1. Four primer pairs used for pathovar-specific polymerase chain reaction detection of Pseudomonas syringae pv. phaseolicola in this study

\begin{tabular}{|c|c|c|c|c|}
\hline Primer pair & Primer sequence 5'-3' & Size (bp) & Gene & References \\
\hline HB14F/HB14R & CCGGTCTGCTCGACATCGACATCGTGCCAC & 1,400 & $\begin{array}{l}\text { Phaseolotoxin } \\
\text { gene cluster }\end{array}$ & Audy et al. 1996 \\
\hline $62 \mathrm{a} / 63 \mathrm{a}$ & $\begin{array}{l}\text { CAACTCCGACACCAGCGACCGACCGAGC } \\
\text { CAATGAAGATTACAAGCCTG }\end{array}$ & $\begin{array}{c}\ldots \\
1,000\end{array}$ & $\arg K^{\cdots}$ & $\begin{array}{l}\ldots \\
\text { Mosqueda-Cano and } \\
\text { Herrera-Estrella } \\
1997\end{array}$ \\
\hline & GCTAGCTATCAGGGGACGAC & $\ldots$ & $\ldots$ & $\ldots$ \\
\hline P3.1/ P5.1 & $\begin{array}{l}\text { TGTTCGGCCAGAGGCAGTCATG } \\
\text { AGCTTCTCCTCAAAACACCTGC }\end{array}$ & $\begin{array}{l}500 \\
\ldots\end{array}$ & pht ${ } \ldots$ & $\begin{array}{c}\text { Schaad et al. } 1995 \\
\ldots\end{array}$ \\
\hline P3004 L/P3004R & $\begin{array}{l}\text { CTGTCTGGCAGCCACTACAAAG } \\
\text { CTGTCTGGCAGCCACTACAAAG }\end{array}$ & $\begin{array}{l}240 \\
\ldots\end{array}$ & $\begin{array}{c}\text { AJ568001 } \\
\ldots\end{array}$ & $\begin{array}{c}\text { Rico et al. } 2006 \\
\ldots\end{array}$ \\
\hline
\end{tabular}


Harbin City, Qiqihaer City, and Duerbote County in Heilongjiang Province; and Shenyang City and Fuxin County in Liaoning Province. The disease symptoms were extremely similar to those of halo blight of bean caused by the quarantined plant pathogen $P$. syringae pv. phaseolicola, which had been reported on bean crops in a few locations in China (Chen and Zhou 2013; Li and Zhang 1990).

Therefore, consecutive multiyear surveys were subsequently conducted from 2010 to 2014 across all of the mung-bean-production regions in China (Fig. 1). The comprehensive survey results showed that the disease occurred in 37 cities or counties in nine provinces: Heilongjiang, Jilin, Liaoning, Inner Mongolia, Beijing, Hebei, Shanxi, Shaanxi, and Xinjiang (Fig. 1; Supplementary Table S1). However, the emerging disease on mung bean was not observed in the remaining six provinces (Shandong, Henan, Jiangsu, Anhui, Hubei, and Chongqing; Fig. 1). The emerging mung bean disease occurred in an area between the northern latitudes of $37.48^{\circ}$ and $48.01^{\circ}$ and eastern longitudes of $87.56^{\circ}$ and $128.05^{\circ}$, which includes three main mung-bean-growing regions: northeastern, northern, and northwestern China (Fig. 1). Generally, the average yields of the fields infected by the emerging disease were reduced 30 to $50 \%$ according to our survey, with yield loss of more than $80 \%$ in the most severely infected fields. The highest incidence of the disease was $100 \%$, causing complete yield losses in Yulin City in Shaanxi Province and Xuanhua County in Hebei Province.

Development of disease symptoms. Mung bean is commonly sown from 15 May to 10 June in three main mung-bean-growing regions: northeastern, northern, and northwestern China. The emerging disease, resembling halo blight, on mung bean was initially observed in early to mid-June. At first, disease symptoms were observed on the lower surfaces of the primary leaves, appearing as small, dark-brown, water-soaked spots (Fig. 2A). Then, the spots rapidly became visible on the upper surfaces of the infected primary leaves. With the lesion expansion, the center of the spot became necrotic and turned gray or white (Fig. 2B). The lesions were also observed on the central vein of
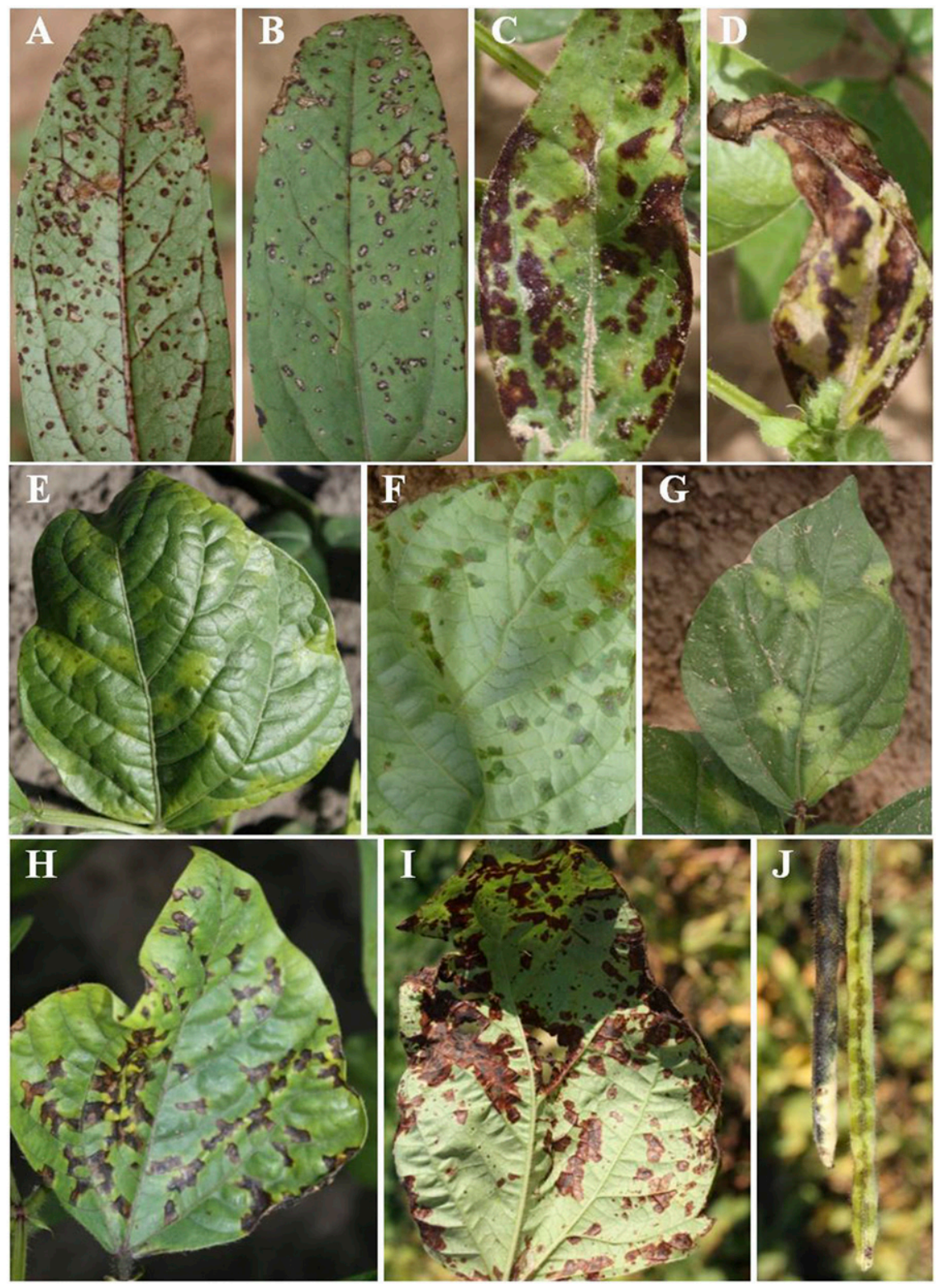

Fig 2. Natural symptoms of halo blight caused by Pseudomonas syringae pv. phaseolicola on mung bean grown in fields. A, Small dark-brown, water-soaked spots and vein necrosis on the lower surface of a primary leaf. B, Lesions with a gray or white necrotic central area on the upper surface of a primary leaf. C, Large circular or irregular dark-brown patches on a primary leaf. D, Primary leaf blight. E, Small water-soaked spots surrounded by chlorotic yellow-green halos on the upper surface of a leaflet. F, Water-soaked spots on the lower surface of a leaflet. G, Small necrotic spots surrounded by large yellow-green halos on the upper surface of a leaflet. $\mathbf{H}$, Angular darkbrown necrotic spots on the upper surface of an old leaf in the late growth stage. I, Large necrotic areas on the lower surface of an old leaf. J, Water-soaked spots or darkbrown to black streaked lesions along pod sutures. 
the primary leaves, leading to vein necrosis. Sometimes, large circular or irregular dark-brown patches appeared on the primary leaves (Fig. 2C), and the lesions expanded and merged together with time, finally resulting in leaf blight (Fig. 2D). With the appearance growth of trifoliolate leaves on plants, the typical halo blight symptoms were observed on trifoliolate leaves (Fig. 2E to G). Small water-soaked spots first appeared on leaflets. Then, the center of the spots soon became necrotic, turned brown to black, and were surrounded by chlorotic zones of yellow-green halos (Fig. 2E to G; Supplementary Fig. $\mathrm{S} 1$ ). Generally, the necrotic centers remained small in size (1 to $2 \mathrm{~mm}$ in diameter). However, the surrounding halos could enlarge to $2 \mathrm{~cm}$ in diameter and were visible on both sides of the leaflets. Young leaflets were the most susceptible, and infected young leaflets became distorted, crinkled, and chlorotic. In severe cases, young seedlings developed systemic chlorosis, and were stunted or even died. Spots on older leaves were usually angular and lacked the halo. The spots could enlarge and coalesce into large necrotic areas with the onset of cool and rainy weather (Fig. 2H to I). The disease was also observed on mung bean petioles and stems. Symptoms began as water-soaked spots, and later extended longitudinally, turning into brown streaks. Mung bean pods were infected after production; the initial symptoms were small water-soaked spots or streaks along the pod sutures, and these lesions turned dark brown to black with age (Fig. 2J).

Pathogen isolation and pathogenicity tests. Bacterial isolates were consistently obtained from collected leaves having halo-blightlike symptoms. Nine representative isolates from nine provinces were selected for pathogenicity tests on Jilv 7 mung bean. The results indicated that all of the isolates were pathogenic to Jilv 7. Typical small, water-soaked spots first appeared on the leaves 5 days after inoculation. Then, the lesions enlarged, turning irregular and brown, with a narrow yellow border or large halo within 10 days. These symptoms were similar to those observed in the field. By contrast, no symptoms were observed on control plants inoculated with sterile tap water. The bacteria were reisolated from the inoculated plants and their characteristics were identical to those of the inoculated isolates. This verified Koch's postulates.

Phenotypic characteristics. The colonies of the isolates grown on $\mathrm{KB}$ and NA plates for $72 \mathrm{~h}$ were creamy white, flat, and circular, with 1- to 3-mm diameters and entire margins (Fig. 3A). The bacterium was gram negative and produced fluorescent pigment on the KB medium under UV light (Fig. 3B). The bacteria were long and rodshaped, 2.2 to 5.5 by 0.8 to $0.9 \mu \mathrm{m}$ in size (Fig. 3C). One to several polar flagella existed at both ends of the bacterial cell (Fig. 3C).

Physiological and biochemical properties. For carbon source utilization, all of the isolates assimilated trigonelline and betaine but were negative for mannitol, inositol, sorbitol, erythritol, anthranilate, homoserine, D-tartrate, L-tartrate, and L-lactate. These results were consistent with the nutritional requirements of the pathogen $P$. syringae pv. phaseolicola. In LOPAT tests, all isolates were positive for levan production and the tobacco hypersensitive reaction but negative for oxidase, potato soft rot, and arginine dihydrolase. These results corresponded to the LOPAT group containing $P$. syringae pathovars.

Fatty acid composition. Twenty-seven different fatty acids were detected in the nine representative isolates from mung bean. All of the isolates contained 10:0 3OH, 12:00, 12:0 2OH, 12:0 3OH, SF3 (16:1 w7c/16:1 w6c), 16:00, 18:1 w7c, and 18:00, and these eight major fatty acids accounted for more than $90 \%$ of the total fatty acids. The fatty acid composition analysis of the nine isolates using the MIDI microbial identification system (version 4.5) and library generation software (version 4.5) identified all of the isolates as $P$. syringae with similarity indexes of 0.503 to 0.954 , which were good matches at the species level (Table 2).

Pathovar-specific PCR detection. Nine representative isolates were identified using four pathovar-specific primers for $P$. syringae pv. phaseolicola (Table 1). The primers HB14R/HB14F and 62a/63a amplified target fragments of 1,400 and $1,000 \mathrm{bp}$, respectively, from all of the isolates (Fig. 4). A duplexed PCR amplification using the primer pairs P5.1/P3.1 and P3004 L/P3004R produced 500- and 240-bp fragments in all of the isolates, respectively.

16S-23S rDNA sequence and phylogenetic analysis. Three isolates (LDI7, LDI8, and LDI9) were selected for 16S-23S rDNA sequence analyses. The resulting $16 \mathrm{~S}-23 \mathrm{~S}$ rDNA sequences of the three isolates were deposited into GenBank (NCBI accession numbers KF888742, KF888743, and KF888744). The 16S-23S rDNA sequences of the three isolates were identical and showed $99 \%$ identity with those of reported $P$. syringae pv. phaseolicola strains (NCBI accession numbers CP000058, D86378, and AY342163) and some $P$. syringae pathovars present in the NCBI database (Fig. 5).

Based on all data for bacterial morphology, physiological and biochemical properties pathogenicity tests, fatty acid composition, and molecular characteristics on pathovar-specific PCR amplification results and the 16S-23S rDNA sequence analysis, the causal agent of the emerging disease on mung bean was identified as $P$. syringae pv. phaseolicola.

Table 2. Fatty acid methyl ester identification of nine bacterial isolates from mung bean grown in nine provinces in China

\begin{tabular}{llcl}
\hline Isolates & Geographic origin & Similarity index & \multicolumn{1}{c}{ Identity } \\
\hline LDI1 & Shenmu, Shaanxi & 0.752 & Pseudomonas syringae \\
LDI2 & Shenyang, Liaoning & 0.767 & P. syringae \\
LDI3 & Baicheng, Jilin & 0.503 & P. syringae \\
LDI4 & Qiqihaer, Heilongjiang & 0.642 & P. syringae \\
LDI5 & Fangshan, Beijing & 0.556 & P. syringae \\
LDI6 & Wulumuqi, Xinjiang & 0.754 & P. syringae \\
LDI7 & Datong, Shanxi & 0.592 & P. syringae \\
LDI8 & Tuqan, Inner Magnolia & 0.803 & P. syringae \\
LDI9 & Xuanhua, Hebei & 0.954 & P. syringae \\
\hline
\end{tabular}

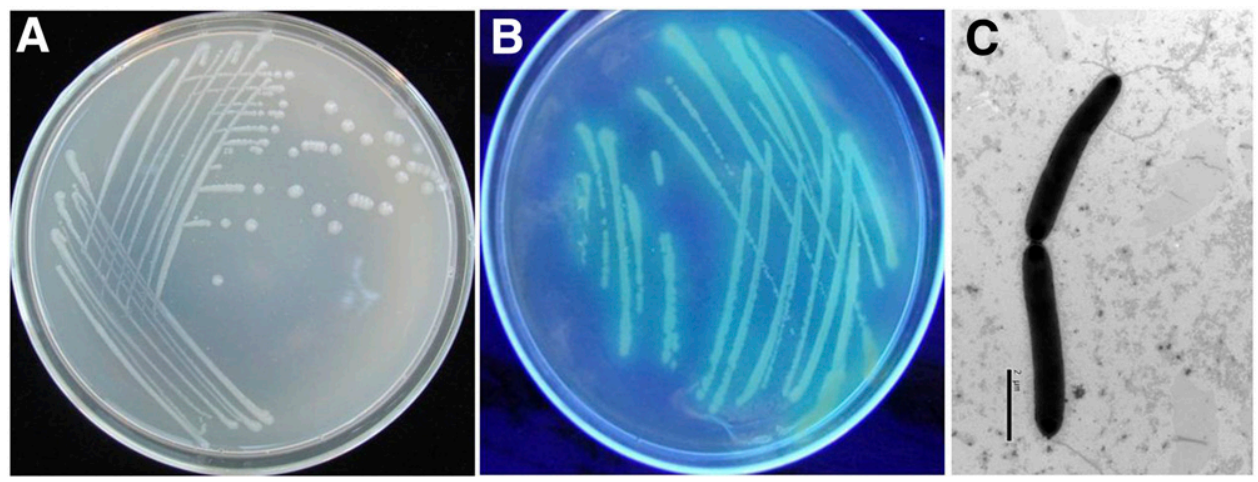

Fig. 3. Colony formation and a micrograph of a Pseudomonas syringae pv. phaseolicola isolate from mung bean. A, Two-day-old colonies on nutrient broth agar medium. B, Bacterium produces fluorescent pigment on King's B medium observed under UV light. C, Morphology of a bacterial cell observed using a transmission electron microscope (scale bar: $2 \mu \mathrm{m}$ ). 


\section{Discussion}

Mung bean is an important food legume and is grown widely in China. In 2009, a new bacterial disease on mung bean, with symptoms resembling those of halo blight, was first found in a major mung bean production area in northeastern China. In a previous study, halo blight also was reported on bean in the northeastern region of China

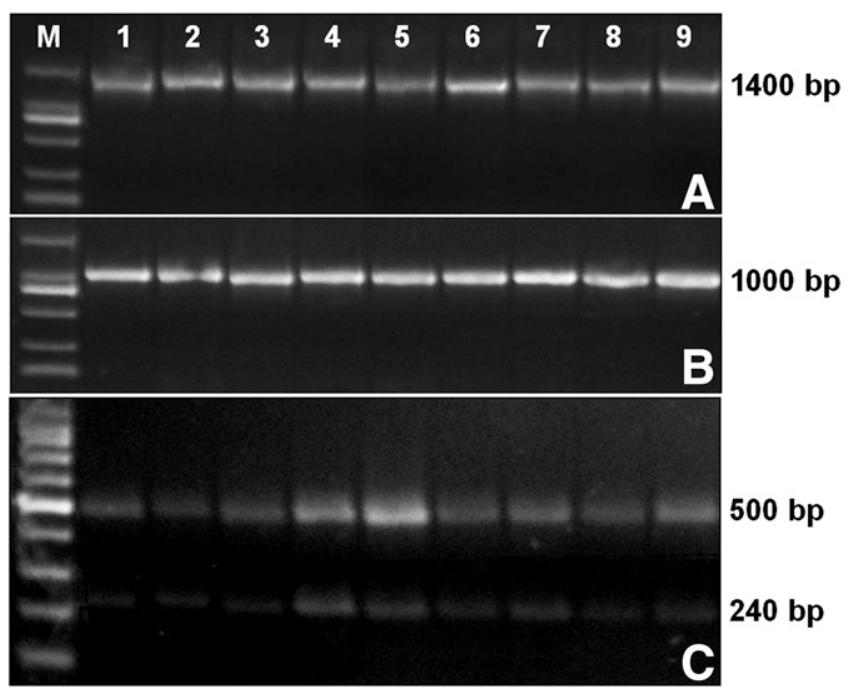

Fig. 4. Polymerase chain reaction amplification patterns of nine representative mung bean isolates of $P$ seudomonas syringae pv. phaseolicola using four pathovar-specific primers. A, Primers HB14R/HB14F amplified a 1,400-bp fragment in every isolate. B, Primers 62a/63a amplified a 1,000-bp fragment. C, Primers P5.1/P3.1 (above) and P3004 L/P3004R (below) amplified 500- and 240-bp fragments, respectively, in a duplexed reaction. Lane M indicates the DNA marker ladder D2000 (A and B) and 100-bp marker ladder (C). Lanes 1 to 9 represent nine mung bean isolates of P. syringae pv. phaseolicola: LDI1, LDI2, LDI3, LDI4, LDI5, LDI6, LDI7, LDI8, and LDI9, respectively.
(Li and Zhang 1990). Because of the discovery of an emerging disease, field surveys were conducted to discern the distribution of the new mung bean disease in China. The results indicated that the halo-blight-like disease had become one of the most important disease of mung bean in China.

Generally, halo blight disease of bean prefers low temperatures at night. The temperature range of 16 to $20^{\circ} \mathrm{C}$ was optimal for halo formation and systemic chlorosis on leaves (Patel and Walker 1963). According to our surveys, the geographic distribution of the mung bean halo-blight-like disease covers the northeastern, northern, and northwestern regions of China. From June to August, these three geographic regions have low daily mean temperatures of 13 to $22^{\circ} \mathrm{C}$ and high daily mean temperatures of 26 to $31^{\circ} \mathrm{C}$. These weather conditions were favorable for disease development and epidemics.

In the field, we observed symptoms of the emerging disease on mung bean that were similar to those of halo blight described on bean and mung bean (Harveson and Schwartz 2007; Patel and Jindal 1972). In addition, we observed lesion development on the primary leaves, old leaves, petioles, leaf veins, and pods through our multiyear surveys (Fig. 1). Based on our observations, the typical halo surrounding the necrotic spot did not form on the primary leaves. The formation of the chlorotic halo surrounding spots on infected leaves is caused by the phaseolotoxin of $P$. syringae pv. phaseolicola (Bender 1999; Mitchell 1976; Tamura et al. 2002). Phaseolotoxin is a nonspecific phytotoxin, which is a potent inhibitor of ornithine carbamoyltransferase and ornithine decarboxylase. Their inhibition could cause chlorophyll synthesis suppression and chlorophyll destruction, respectively, which leads to the chlorotic symptoms (Bachmann et al. 1998; Bender 1999; Ferguson and Johnston 1980). The production of phaseolotoxin is regulated by temperature, and the optimal temperature for phaseolotoxin production is $18^{\circ} \mathrm{C}$. For bean, Turner and Mitchell (1985) found that clear halo symptoms only develop on the primary leaves of the youngest seedlings 6 to 7 days after germination. However, the halo lesions did not appear on primary leaves of more than 14-day-old seedlings, in which the chlorophyll concentration had reached its maximum. Therefore, halos could only

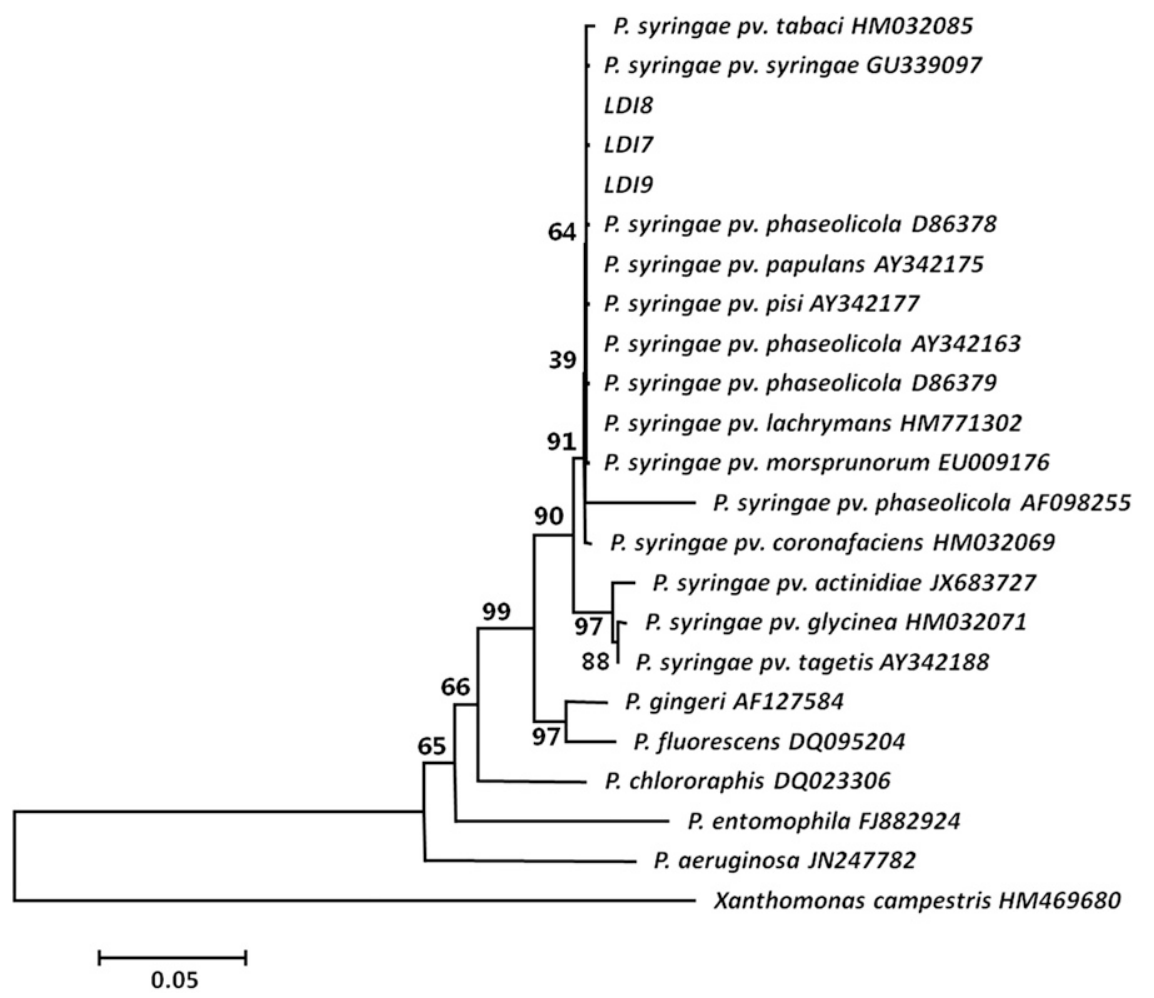

Fig. 5. Phylogenetic analysis of 16S-23S ribosomal DNA sequences of mung bean bacterial isolates (LDI7, LDI8, and LDI9) and reported Pseudomonas species and $P$. syringae pathovars. The tree was rooted using the bacterium Xanthomonas campestris. Neighbor-joining bootstrapping values are shown above of branching nodes (1,000 bootstraps). 
be induced in those leaves that were expanding and synthesizing chlorophyll in cool weather conditions (Patel and Walker 1963).

The infection of primary leaves could be induced from infected seed. Therefore, early discrimination and diagnosis of mung bean halo-blight-like symptoms on primary leaves is conducive to the early eradication or control of disease spread in the field. Epidemics of mung bean halo blight are closely associated with planting seed already infected by $P$. syringae pv. phaseolicola in the field (Schmitthenner et al. 1971).

Until now, halo blight on mung bean had been reported in only a few countries. In previous studies, the causal agent of halo blight on mung bean was identified as $P$. syringae pv. phaseolicola (syn. $P$. phaseolicola) based on morphological, physiological, and biochemical properties (Akhtar 1988; Patel and Jindal 1972; Schmitthenner et al. 1971). In this study, the identity of the pathogen causing halo-blight-like symptoms on mung bean in China was also determined to be $P$. syringae pv. phaseolicola based on comprehensive phenotypic, physiological, and biochemical characteristics; pathogenicity tests; fatty acid composition; and molecular analyses. The phenotypic, physiological, and biochemical characteristics; pathogenicity test results; fatty acid composition; and molecular sequence analyses of the mung bean isolates corresponded to those of $P$. syringae pv. phaseolicola isolates reported in previous studies (Akhtar 1988; Güven et al. 2004; Jeon et al. 2006; Patel and Jindal 1972; Sawada et al. 1997).

Morphologically, we found that the bacterial cell size was somewhat different than that of the previously reported $P$. syringae pv. phaseolicola isolates from mung bean and kudzu vine. Akhtar (1988) measured the size of mung bean isolates as 1.2 to 6.0 by 1.4 to $3 \mu \mathrm{m}$. Jeon et al. (2006) reported that the kudzu vine isolates were 1.5 by 0.7 to $0.8 \mu \mathrm{m}$. These differences may be caused by different origins, hosts, or cultural conditions. Some factors such as temperature, nutrients, and the osmolarity of the growth medium have been reported to affect the size of bacteria (Monier and Lindow 2003).

In the analysis of carbon source utilization, our isolates did not assimilate mannitol. The isolates' carbon source utilization corresponded to that of bean isolates of $P$. syringae pv. phaseolicola (Birch et al. 1981; Güven et al. 2004; Völksch and Weingart 1997) but contrasted with those of Indian mung bean (Patel and Jindal 1972), yam bean (Birch et al. 1981), and kudzu vine (Jeon et al. 2006; Völksch and Weingart 1997) isolates.

In this study, three pathovar-specific primer pairs (HB14R/ HB14F, 62a/63a, and P5.1/P3.1) targeting toxigenic isolates of $P$. syringae pv. phaseolicola that contained phaseolotoxin gene clusters, amplified expected target fragments in our mung bean isolates (Audy et al. 1996; Mosqueda-Cano and Herrera-Estrella 1997; Schaad et al. 1995) (Fig. 4). The results indicated that the nine representative isolates belonged to toxigenic strains of $P$. syringae pv. phaseolicola containing a phaseolotoxin gene. Whereas the primer pair P3004 L/P3004R did not yield the expected results (Rico et al. 2006), the primers P3004 L/P3004R amplified a 240-bp target fragment in our isolates (Fig. 4) which had previously been observed only in nontoxigenic strains (Oguiza et al. 2004). The primer pair P3004 L/P3004R may lack the specificity to discriminate between toxigenic and nontoxigenic isolates of $P$. syringae pv. phaseolicola from different origins or genetic backgrounds.

Previous studies revealed that $P$. syringae pv. phaseolicola isolates from mung bean and bean have different pathogenic capabilities, nutritional requirements, and genetic characteristics (Marques et al. 2000; Patel and Jindal 1972, Schmitthenner et al. 1971). This might be because mung bean originated from the old world (India) and bean from the new world (America). Patel and Jindal (1972) hypothesized that mung bean and bean isolates of $P$. syringae pv. phaseolicola evolved independently from some common saprophytic ancestors and that the host played an important role in the nature of the parasitic, nutritional, and other changes that accompanied evolution. In this study, our mung bean isolates also showed a few minor differences compared with various host isolates of $P$. syringae pv. phaseolicola in morphology, carbon source utilization, and molecular characteristics, although our mung bean isolates also caused $P$. syringae pv. phaseolicola-associated symptoms, including watersoaked lesions on bean cotyledons and pods as determined by pathogenicity tests (data not shown). A further comparative analysis of mung bean and bean isolates of $P$. syringae pv. phaseolicola should be conducted to reveal all of the differences.

A comprehensive field survey of the geographic distribution of the emerging disease, halo blight on mung bean, was conducted in China. The survey results revealed that mung bean halo blight has been rapidly spreading and is prevalent in the three major mungbean-producing regions (northeastern, northern, and northwestern China). By our multiyear field survey, the development of halo blight symptoms on mung bean was clearly observed and demonstrated on leaves, stems, petioles, and pods. The causal agent of the disease was confirmed as $P$. syringae pv. phaseolicola using morphological, physiological, and biochemical characteristics; pathogenicity tests; as well as specific PCR amplification assays and 16S-23S rDNA sequence analyses. To out knowledge, this is the first report of mung bean halo blight caused by $P$. syringae pv. phaseolicola in China.

\section{Acknowledgments}

We thank J. Tian at Hebei Academy of Agricultural and Forestry Sciences for providing the mung bean seed used in this study. This study was supported by the Modern Agro-industry Technology Research System (CARS-09) and the Scientific Innovation Program of the Chinese Academy of Agricultural Sciences.

\section{Literature Cited}

Akhtar, M. A. 1988. Pseudomonas syringae pv. phaseolicola on mungbean. Pak. J. Agric. Res. 9:424-426.

Arnold, D. L., Lovell, H. C., Jackson, R. W., and Mansfield, J. W. 2011. Pseudomonas syringae pv. phaseolicola: From 'has bean' to supermodel. Mol. Plant Pathol. 12:617-627.

Audy, P., Braat, C. E., Saindon, G., Huang, H. C., and Laroche, A. 1996. A rapid and sensitive PCR-based assay for concurrent detection of bacteria causing common and halo blights in bean seed. Phytopathology 86:361-366.

Bachmann, A. S., Matile, P., and Slusarenko, A. J. 1998. Inhibition of ornithine decarboxylase activity by phaseolotoxin: implications for symptom production in halo blight of French bean. Phys. Mol. Plant. Pathol. 53:287-299.

Bender, C. L. 1999. Chlorosis-inducing phytotoxins produced by Pseudomonas syringae. Eur. J. Plant Pathol. 105:1-12.

Birch, R. G., Alvarez, A. M., and Patilm, S. S. 1981. A bacterial leaf spot caused in Yam bean by Pseudomonas syringae pv. phaseolicola. Phytopathology 71: 1289-1293.

Burkholder, W. K. 1926. A new bacterial disease of the bean. Phytopathology 16:915-928.

Chen, Y. L., and Zhou, L. H. 2013. Identification of pathogens of Pseudomonas syringae pv. phaseolicola for Phaseolus vulgaris. Hunan Agric. Sci. 100: 91-93. (In Chinese with English abstract)

Conde, B. D., and Diatloff, A. 1991. Diseases of mungbeans. Pages 73-77 in: Mungbean: The Australian Experience. Proc. First Aust. Mungbean Workshop. Division of Tropical Crops and Pastures, CSIRO, Brisbane, Australia.

Cui, X. Y., Shen, L., Yuan, X. X., Gu, H. P., and Chen, X. 2014. First report of bean common mosaic virus infecting mungbean (Vigna radiata) in China. Plant Dis. 98:1590.

Dahiya, P. K., Linnemann, A. R., Van Boekel, M. A. J. S., Khetarpaul, N., Grewal, R. B., and Nout, M. J. R. 2015. Mung bean: Technological and nutritional potential. Crit. Rev. Food Sci. Nutr. 55:670-688.

Ferguson, A. R., and Johnston, J. S. 1980. Phaseolotoxin: chlorosis, ornithine accumulation and inhibition of ornithine carbamoyltransferase in different plants. Phys. Plant Pathol. 16:269-275.

Güven, K., Jones, J. B., Momol, M. T., and Dickstein, E. R. 2004. Phenotypic and genetic diversity among Pseudomonas syringae pv. phaseolicola. J. Phytopathol. 152:658-666.

Harveson, R. M., and Schwartz, H. F. 2007. Bacterial diseases of dry edible beans in the central high plains. Online publication. Plant Health Prog. doi:10.1094/ PHP-2007-0125-01-DG

Hunter, P. J., and Taylor, J. D. 2006. Patterns of interaction between isolates of three pathovars of Pseudomonas syringae and accessions of a range of host and non-host legume species. Plant Pathol. 55:46-53.

Jeon, Y. H., Chang, S. P., Kim, S. G., and Kim, Y. H. 2006. Halo blight of kudzu vine caused by Pseudomonas syringae pv. phaseolicola in Korea. Plant Pathol. J. 22:119-124.

King, E. O., Ward, M. K., and Raney, D. E. 1954. Two simple media for the demonstration of pyocyanin and fluorescin. J. Lab. Clin. Med. 44: 301-307.

Lamichhane, J. R., Messéan, A., and Morris, C. E. 2015. Insights into epidemiology and control of diseases of annual plants caused by the Pseudomonas syringae species complex. J. Gen. Plant Pathol. 81:331-350. 
Lelliott, R. A., Billing, E., and Hayward, A. C. 1966. A determinative scheme for the fluorescent plant pathogenic pseudomonads. J. Appl. Bacteriol. 29:470-489.

Li, X., and de Boer, S. H. 1995. Selection of polymerase chain reaction primers from an RNA intergenic spacer region for specific detection of Clavibacter michiganensis subsp. spedonicus. Phytopathology 85:837-842.

Li, X., Nie, J., Ward, L., Madani, M., Hsiang, T., Zhao, Y., and De Boer, S. H. 2009. Comparative genomics-guided loop-mediated isothermal amplification for characterization of Pseudomonas syringae pv. phaseolicola. J. Appl. Microbiol. 107:717-726.

Li, Y. H., and Zhang, X. M. 1990. A new bean disease: Bacterial halo blight. Plant Prot. 16:52. (In Chinese)

Marques, A. S. dos A., Corbière, R., Gardan, L., Tourte, C., Manceau, C., Taylor, J. D., and Samson, R. 2000. Multiphasic approach for the identification of the different classification levels of Pseudomonas savastanoi pv. phaseolicola. Eur. J. Plant Pathol. 106:715-734.

Mitchell, R. E. 1976. Isolation and structure of a chlorosis-inducing toxin of Pseudomonas phaseolicola. Phytochemistry 15:1941-1947.

Monier, J.-M., and Lindow, S. E. 2003. Pseudomonas syringae responds to the environment on leaves by cell size reduction. Phytopathology 93:1209-1216.

Mosqueda, G., Van den Broeck, G., Saucedo, O., Bailey, A. M., Alvarez-Morales, A., and Herrera-Estrella, L. 1990. Isolation and characterization of the gene from Pseudomonas syringae pv. phaseolicola encoding the phaseolotoxininsensitive ornithine carbamoyltransferase. Mol. Genet. Genomics 222:461-466.

Mosqueda-Cano, G., and Herrera-Estrella, L. 1997. A simple and efficient PCR method for the specific detection of Pseudomonas syringae pv. phaseolicola in bean seeds. World J. Microbiol. Biotechnol. 13:463-467.

Nair, R. M., Yang, R. Y., Easdown, W. J., Thavarajah, D., Thavarajah, P., Hughes, J. D. A., and Keatinge, J. D. H. 2013. Biofortification of mung bean (Vigna radiata) as a whole food to enhance human health. J. Sci. Food Agric. 93: 1805-1813.

Oguiza, J. A., Rico, A., Rivas, L. A., Sutra, L., Vivian, A., and Murillo, J. 2004. Pseudomonas syringae pv. phaseolicola can be separated into two genetic lineages distinguished by the possession of the phaseolotoxin biosynthetic cluster. Microbiology 150:473-482.

Patel, P. N., and Jindal, J. K. 1972. Bacterial leaf spot and halo blight diseases of mung bean (Phaseolus aureus) and other legumes in India. Indian Phytopathol. 25:517-525.

Patel, P. N., and Walker, J. C. 1963. Relation of air temperature and age and nutrition of the host to the development of halo and common bacterial blights of bean. Phytopathology 53:407-411.

Patel, P. N., and Walker, J. C. 1965. Resistance in Phaseolus to halo blight. Phytopathology 55:889-894

Peet, R. C., Lindgren, P. B., Willis, D. K., and Panopoulos, N. J. 1986. Identification and cloning of genes involved in phaseolotoxin production by Pseudomonas syringae pv. phaseolicola. J. Bacteriol. 166:1096-1105.

Prosen, D., Hatziloukas, E., Schaad, N. W., and Panopoulos, N. J. 1993. Specific detection of Pseudomonas syringae pv. phaseolicola DNA in bean seed by polymerase chain reaction-based amplification of a phaseolotoxin gene region. Phytopathology 83:965-970.

Rico, A., Erdozáin, M., Barredo, A. O., de Galarreta, J. R., and Murillo, J. 2006. Detection by multiplex PCR and characterization of nontoxigenic strains of Pseudomonas syringae pv. phaseolicola from different places in Spain. Span. J. Agric. Res. 4:261-267.

Rico, A., López, R., Asensio, C., Aizpún, M. T., Asensio-S.-Manzanera, M. C., and Murillo, J. 2003. Nontoxigenic strains of Pseudomonas syringae pv. phaseolicola are a main cause of halo blight of beans in Spain and escape current detection methods. Phytopathology 93:1553-1559.

Sawada, H., Takeuchi, T., and Matsuda, I. 1997. Comparative analysis of Pseudomonas syringae pv. actinidiae and pv. phaseolicola based on phaseolotoxin-resistant ornithine carbamoyltransferase gene $(\operatorname{argK})$ and $16 \mathrm{~S}-23 \mathrm{~S}$ rRNA intergenic spacer sequences. Appl. Environ. Microbiol. 63:282-288.

Schaad, N. W., Cheong, S. S., Tamaki, S., Hatziloukas, E., and Panopoulos, N. J. 1995. A combined biological and enzymatic amplification (BIO-PCR) technique to detect Pseudomonas syringae pv. phaseolicola in bean seed extracts. Phytopathology 85:243-246.
Schaad, N. W., Jones, J. B., and Chun, W. 2001. Laboratory Guide for Identification of Plant Pathogenic Bacteria, 3rd ed. American Phytopathological Society, St. Paul, MN.

Schmitthenner, A. F., Hoitnik, H. A. J., and Kroetz, M. E. 1971. Halo blight of mungbean incited by a new strain of Pseudomonas phaseolicola. (Abstr.) Phytopathology 61:909.

Schuster, M. L. 1955. A method of testing resistance of beans to bacterial blights. Phytopathology 45:519-520.

Silva, L. R., Pereira, M. J., Azevedo, J., Gonçalves, R. F., Valentão, P., de Pinho, P. G., and Andrade, P. B. 2013. Glycine max (L.) Merr., Vigna radiata L. and Medicago sativa L. sprouts: A natural source of bioactive compounds. Food Res. Int. 50:167-175.

Tamura, K., Imamura, M., Yoneyama, K., Kohno, Y., Takikawa, Y., Yamaguchi, I., and Takahashi, H. 2002. Role of phaseolotoxin production by Pseudomonas syringae pv. actinidiae in the formation of halo lesions of kiwifruit canker disease. Physiol. Mol. Plant Pathol. 60:207-214.

Tamura, K., Stecher, G., Peterson, D., Filipski, A., and Kumar, S. 2013. MEGA6: molecular evolutionary genetics analysis version 6.0. Mol. Biol. Evol. 30: 2725-2729.

Tang, D., Dong, Y., Ren, H., Li, L., and He, C. 2014. A review of phytochemistry, metabolite changes, and medicinal uses of the common food mung bean and its sprouts (Vigna radiata). Chem. Cent. J. 8:4-9.

Taylor, J. D., Phelps, K., and Dudley, C. L. 1979. Epidemiology and strategy for the control of halo-blight of beans. Ann. Appl. Biol. 93:167-172.

Taylor, J. D., Teverson, D. M., Allen, D. J., and Pastor-Corrales, M. A 1996. Identification and origin of races of Pseudomonas syringae pv. phaseolicola from Africa and other bean growing areas. Plant Pathol. 45: 469-478.

Turner, J. G., and Mitchell, R. E. 1985. Association between symptom development and inhibition of ornithine carbamoyltransferase in bean leaves treated with phaseolotoxin. Plant Physiol. 79:468-473.

van Schoonhoven, A., and Voysest, O. 1989. Common beans in Latin America and their constraints. Pages 33-57 in: Bean Production Problems in the Tropics, 2nd ed. CIAT, Cali, Colombia.

Völksch, B., and Weingart, H. 1997. Comparison of ethylene-producing Pseudomonas syringae strains isolated from kudzu (Pueraria lobata) with Pseudomonas syringae pv. phaseolicola and Pseudomonas syringae pv. glycinea. Eur. J. Plant Pathol. 103:795-802.

Wang, L. X., Cheng, X. Z., and Wang, S. H. 2009. Advances in research on genetic resources, Breeding and genetics of mungbean (Vigna radiata L.). Sci. Agric. Sin. 42:1519-1527.

Webster, R. M., Atkin, J. D., and Cross, J. E. 1983. Bacterial blights of snap beans and their control. Plant Dis. 67:935-940.

Yang, W., Liu, Y., Liu, X., Shao, P., Chen, Y., and Zhao, W. 2015. Detection of Pseudomonas savastanoi pv. phaseolicola in imported soybean by nested PCR. Chin. J. Oil Crop Sci. 37:113-118. (In Chinese with English abstract).

Young, J. M. 2010. Taxonomy of Pseudomonas syringae. J. Plant Pathol. 92: S1.5-S1.14.

Yue, Y., Ren, Y., Zhang, L., Jin, G., Wang, C., and Li, G. 2015. Identification of the pathogen causing mung bean Verticillium wilt in Xinjiang. Xinjiang Agric. Sci. 52:1477-1480.

Zeng, Z., Wang, Q., Lin, W., and Zhou, S. 2011. Quality characteristics and utilization of mungbean. Crops 14:16-19. (In Chinese with English abstract).

Zhang, J. Q., Zhu, Z. D., Duan, C. X., Wang, X. M., and Li, H. J. 2011. First report of charcoal rot caused by Macrophomina phaseolina on mungbean in China. Plant Dis. 95:872.

Zhang, Y., Rowley, K. B., and Patil, S. S. 1993. Genetic organization of a cluster of genes involved in the production of phaseolotoxin, a toxin produced by Pseudomonas syringae pv. phaseolicola. J. Bacteriol. 175:6451-6458.

Zhang, Y. X., and Patil, S. S. 1997. The phtE locus in the phaseolotoxin gene cluster has ORFs with homologies to genes encoding amino acid transferases, the AraC family of transcriptional factors, and fatty acid desaturases. Mol. Plant-Microbe Interact. 10:947-960.

Zhu, Z. D., and Duan, C. X. 2012. Identification and Control of Diseases and Pests in Mung Bean. China Agriculture Science and Technology Press, Beijing. (In Chinese) 